\title{
Sobre a infecção do M. RHESUS pela deposição de fezes de mosquitos infectados sobre a pelle ou na conjunctiva ocular integras ( $\left.{ }^{1}\right)$.
}

\author{
Pelos Drs. H. de BEAUREPAIRE ARAGÃO e A. da COSTA LIMA.
}

Proseguindo no plano de experiencias que vimos emprehendendo, relativas á infecção do Macacus rhesus pelas fezes de mosquitos infectados, procurámos verificar se a diluição de fezes, obtida segundo a technica descripła no nosso trabalho anterior $\left({ }^{2}\right)$, poderia tambem infectar o rhesus, quando deposta sobre a pelle ou na conjunctiva ocular, apparentemente sem qualquer solução de continuidade. Escolhemos para isso dois macacos, depois de termos verificado, com o auxilio de uma lente binocular, a integridade das regiões que iam receber o liquido infectante.

No primeiro, rhesus no. 427, instillámos algumas gottas desse liquido numa das conjunctivas e no outro, rhesus no. 428, deixámos cahir a outra parte do liquido sobre o tegumento intacto da região inguinal, sem arrancamento ou raspagem dos pêlos dessa região.

Fizemos a diluição empregando excreta de 9 mosquitos infectados no rhesus no. 373, a 18 de abril, colhidas pouco depois daquelles terem picado uma cobaya sã.

Ambas as experiencias foram iniciadas a 21 de maio.

EXPERIENCIA 1. $M$. rhesus no. 427. Temperatura: 380,8 .

Nos 2 dias que se seguiram e até o dia 28 a temperatura não foi além de 390,8. A 29, porém, ascendeu a 400,3, sendo o macaco sangrado no coração e o sangue inoculado no rhesus no. 443. A 30 baixou a 400,1 e a 31 a 390 . D'esse dia em deante houve ligeiras fluctuações thermicas em torno de $39 \circ$. A 4 a temperatura baixou a 370,8 , sendo então o macaco sacrificado.

As visceras apresentavam-se como nos casos de febre amarella. Todavia o exame histo-pathologico mostrou o seguinte: arranjo das traves conservado; infiltração gordurosa periporta. Não havia inclusões nucleares, nem necrose das cellulas hepaticas.

EXPERIENCIA 2. $M$. rhesus no. 443. Inoculado a 29 de maio com 5 cc. de sangue retirado do rhesus n. 427. Temperatura 390,2.

A 2 de Junho, ascendeu a 390,9 , a 3 a 400,7 e, á tarde do mesmo dia, a $411^{\circ}$. A 4 baixou a $37^{\circ}$. A's 15 horas o macaco foi sacrificado. Lesฮes macroscopicas typicas.

(1) Entregue para publicação em 16 de Julho de 1929.

(2) ARAGÃO, Dr. H. BEAUREPAIRE e COSTA LIMA, Dr. A. da.-Sobre a transmissão do virus da febre amarella pelas fezes de mosquitos infectados. Apresentado á Sociedade Brasileira de Biologia, em sessão de 29 de Maio de 1929 e publicado no Brasil-Medico, 1929, XLIII, 24, 15 de Junho, 669-671 e no Supplemento das Memorias, Instituto Oswaldo Cruz, 8, 22 de Junho de 1929, 101-108, 2 figs. 
O exame histo-pathologico do figado revelou: inclusões nucleares, extensa neciose e degeneração gordurosa das cellulas hepaticas. Fócos de infiltração por polymorpho-nucleares.

EXPERIENCIA 3. $M$. rhesus no. 428, sobre cujo tegumento deixámos a referida diluição cerca de meia hora, soltando-o depois na gaiola. Nos dias seguintes e até o dia 27 , apresentou temperaturas ou superiores de alguns decimos, ou pouco inferiores a 390. A 28 a temperatura subio a $40^{\circ}, 3$, descendo, no dia seguinte, a $40^{\circ}$, sendo então o macaco sangrado e o sangue inoculado no rhesus no. 445.

A 30 , pela manhã, encontrámos o macaco morto. As visceras apresentavam o aspecto typico que se observa nos casos de febre amarella, notando-se abundante hemorrhagia no estomago. O exame histo-pathologico do figado confirmou essa verificação, notando o $\mathrm{Dr}$. M. TORRES o seguinte: desarranjo das traves, intensa necrose, degeneração gordurosa das cellulas do figado e inclusð̃es nucleares. Congestão.

EXPERIENCIA 4. M. rhesus no. 445. Inoculado a 29 de Maio com 0,5 ce. de sangue do rhesus $11^{\circ}$. 428. Temperatura no inicio da experiencia: 390,3 . No dia seguinte 390,6 e a $31,39 \circ, 7$. A 10 de Junho a temperatura ascendeu a 40 ,5. No dia immediato, isto é, 3 dias depois da inoculação, encontrámos o macaco morto na gaiola, sendo autopsiado tardiamente.

O exame histo-pathologico revelou: "inclusões nncleares pouco numerosas nas cellulas hepaticas, que apresentavam degeneração parenchymatosa. A necrose das cellulas do figado não poude ser devidamente apreciada" (TORRES).

Enıbora as experiencias acima demonstrem claramente que um ataque de febre amarella pode ser obtido no rhesus pela simples deposição de fezes infectantes na conjunctiva e na pelle, nós considerámos necessario repetir aquella que se referia a esse ultimo modo de transmissão.

Com esse objectivo foram usados 2 macacos, $n^{\circ} .448$ para ser infectado pela picada através de uma flanella e no. 449 para ser infectado pela simples deposição de fezes sobre a pelle intacta.

EXPERIENCIA 5. $M$. rhesus no. 449. Sobre a pelle do pescoço deste macaco foram depositadas, no dia 3 de Junho á tarde, algumas gottas de uma diluição de excreta expellidos por 9 dos mosquitos usados na experiencia de controle no. 7 .

Sendo possivel que o macaco houvesse arranhado o ponto em que fora depositado o virus, examinamol-o, na manhã seguinte, e verificámos que a pelle estava absolutamente integra. A temperatura era de 3902 . Nos dias seguintes, até 7 de Jnnho, nenhuma elevação acima de 3903 . Neste dia a temperatura se elevou a 490,1 e o animal foi sangrado no coração. No dia seguinte a temperatura foi de $40^{\circ}$, no dia 9 baixou a 390,5 e assim se manteve por 2 dias. Nos dias 12 e 13 nova elevação a $40^{\circ}, 2$, sendo o macaco de novo sangrado no coração. Até o dia 20 a temperatura se manteve entre $39 \circ$ e 40 . No dia 21 a temperatura era de 390,7 e para sabermos se este rhesus no. 449 estava immune foi elle injectado com 0,5 cc. de sangue contendo virus do rhesus no. 476. Nos dias 22 e 23 a termperatura se elevou acima de 390,5 ; no dia 24 subiu a 400,3 e no dia 25 a 400,9 para cahir a $38^{\circ}, 3$ no dia 26 . No dia 27 o macaco foi encontrado morto na gaiola. A autopsia revelou lesões macroscopicas typicas e o exame histo- 
pathologico do figado deu o seguinte resultado: "intensa degeneração gordurosa e discreta necrose das cellulas hepaticas. Numerosas inclusões nucleares especificas" (TORRES).

Surge aqui a questão de se saber si o rhesus no. 449 estava infectado com o material de excreta depositado sobre a pelle ou o foi sómente pelo virus do rhesus no. 476.

A experiencia subsequente vae nos tirar essa duvida.

EXPERIENCIA 6. M. rhesus no. 467 foi injectado por via subcutanea em 14 de Junho com 1 cc. de uma mistura dos sangues do rhesus no. 449 colhidos em 7,12 e 13. Temperatura: 390.

No dia 14 a temperatura do macaco era de $39 \circ, 4$ e no dia 15 de 40 ?, temperatura essa que se manteve por 7 dias com pequenas oscillações.

No dia 23 de. Junho a temperatura foi de 390,8 e no dia seguinte cahiu a 380,6 . O macaco morreu durante a noite apresentando as visceras todas as apparencias de febre amarella. O exame histo-pathologico do figado mostrou extensa necrose das cellulas hepaticas, degenerəção gordurosa, corpusculos intranucleares e congestão.

Esta experiencia demonstra que o rhesus no. 449 estava de facto infectado com o virus da febre amarella anteriormente á inoculação do sangue do rhesus no. 476, que o superinfectou.

EXPERIENCIA 7. M. rhesus no. 448. Foi picado em 3 de Junho por 12 mosquitos (as dejecções de 9 destes mosquitos foram usadas na experiencia 5) que tinham picado 28 dias antes o rhesus infectado no. 405. Temperatura 390.

As primeiras elevações de temperatura foram pouco accentuadas até os dias 7 e 8 em que ella se elevou a 39n,9. Desta data até a 21 a temperatura, ora baixa, ora alta, não excedeu a 390,9 . No dia 21 , estando o macaco com 390,2 foi elle inoculado com $1 \mathrm{cc}$. de sangue do rhesus infectado no. 476 , não tendo o macaco apresentado nenhuma reacção em seguida a esta inoculação a contrario do que aconteceu com o rhesns no. 449 , como já ficou anteriormente assignalado.

O resultado desta experiencia mostra a possibilidade de uma infecção benigna num rhesus que foi picado por 12 mosquitos que 28 dias antes tinham sugado um rhesus infectado.

Em vista dos resultados acima citados nós estamos convencidos que os excreta de mosquitos infectados, quando simplesmente collocados sobre a pelle integra, são sufficientes para produzir casos de febre amarella experimental no Macacus rhesus. 